\title{
Antibiotic prescribing pattern among paediatric patients attending tertiary care hospital in South India
}

\author{
R. P. Priyadharsini*, R. Kesavan
}

Department of Pharmacology, JIPMER, Karaikal, Puducherry, India

Received: 04 May 2020

Revised: 11 June 2020

Accepted: 12 June 2020

*Correspondence:

Dr. R. P. Priyadharsini,

Email: drpriya.rp@gmail.com

Copyright: $@$ the author(s), publisher and licensee Medip Academy. This is an open-access article distributed under the terms of the Creative Commons Attribution Non-Commercial License, which permits unrestricted non-commercial use, distribution, and reproduction in any medium, provided the original work is properly cited.

\section{ABSTRACT}

Background: The usage of antibiotics among paediatric age group in India is on the higher side, that more than $60 \%$ of children in the age group 0 to 4 years received antibiotics. The higher use of antibiotics results in antibiotic resistance, increased health care costs, adverse drug reaction and may complicate the treatment of infections in future. There is a continuous need to monitor the prescription of antibiotics at all health care levels to prevent antibiotic resistance.

Methods: A prospective and descriptive study was conducted in one of the pharmacies which dispenses the paediatric prescriptions in a tertiary hospital. The prescriptions used to treat infection were collected and analysed. A total of 500 prescriptions were collected and analysed.

Results: The prescriptions were analysed for the WHO prescribing indicators. The average number of drugs per prescription is 1.84 with $21 \%$ of the prescriptions containing antibiotics. The most commonly prescribed antibiotics were penicillin like amoxycillin, phenoxymethyl penicillin followed by cotrimoxazole and cephalosporin group of antibiotics. The antibiotics prescribed belonged to the access group of antibiotics. The percentage of the prescriptions with drugs form essential drugs list and prescribed with generic name is $65.8 \%$ and $67 \%$ respectively. There were no injections prescribed.

Conclusions: The antibiotic prescribing pattern and the average drugs per prescription falls with the WHO range indicating reduced use of antibiotics and absence of polypharmacy. However, the prescription of generic drugs and the drugs from the essential drug list is less.

Keywords: Paediatric, Antibiotic, Resistance, Drug utilization, WHO prescription indicators

\section{INTRODUCTION}

India is a country with a higher prevalence of infectious diseases and antibiotic prescription rate. It was identified that for every 1000 prescriptions in private hospitals 636 patients were prescribed antibiotics in the children age group 0-4 years. ${ }^{1,2}$ As per WHO bulletin, the incidence of antibiotic usage was higher in the children between 6 months and 1 year of age in all the sites of eight countries and in the second year of life in Vellore Southern India. ${ }^{3}$ A higher usage of antibiotics in children less than 5 years was observed in a cross sectional study in Indonesia. The antibiotics were used for the common infections which does not require antibiotics. ${ }^{4}$ Over usage of antibiotics can lead to adverse effects, super infections, and antibiotic resistance. ${ }^{5}$ The resistance of the streptococcus pyogenes to macrolides, resistance to mupirocin which eradicates Methicillin-resistant Staphylococcus aureus infection, the resistance of Enterococcus to vancomycin, resistance of mycoplasma pneumonia to macrolides, carbapenam resistance in Enterobacteriaceae, is increasing. ${ }^{6}$ The factors that are associated with increasing antibiotic resistance in India are high prevalence of disease, increased use of antibiotics in 
poultry, easy access to antibiotics, irrational dispensing and misuse of antibiotics. ${ }^{7}$ In 2010 New Delhi beta lactamase was discovered and this enzyme increased the resistance of bacteria towards higher antibiotics like carbapenams which led to the implementation of schedule H1 i.e., control on the over the counter use of antibiotics. ${ }^{8,9}$ The supervision audit and feedback of the prescribing pattern is one of the key intervention to ensure rational use of medicines. ${ }^{10}$ The core elements of the antibiotic stewardship also include intervention of pharmacy expertise to monitor the antibiotic use. ${ }^{11}$ The aim of the present study was to assess the prescription pattern among the paediatric patients attending the outpatient department in a tertiary care hospital.

\section{METHODS}

The study was conducted in the one of the pharmacies which dispenses the paediatric medications in JIPMER, Puducherry from June to September 2019. It is a prospective cross-sectional study planned after obtaining the waiver of consent from the institute ethics committee. The pharmacy dispenses the medications for patients in obstetrics, gynaecology and paediatrics. The investigator visited the pharmacy and photographed the prescriptions. The prescription was collected in the morning at least twice a week in the months of June to September and around 500 prescriptions were photographed.

\section{Inclusion criteria}

The paediatric patients treated for common infections were included.

\section{Exclusion criteria}

Exclusion criteria were the paediatric patients who were treated for nutritional deficiency and the epileptic paediatric patients who were also treated for infections.

The information available in the digital copies of the prescriptions was entered in excel and used to analyse the WHO prescribing indicators excel and the values are expressed as percentage.

\section{RESULTS}

The total number of patients were 500 out of which 302 were males and 198 were females. The maximum patient population belonged to the male gender and age group 5 to 10 years (Table 1). The average number of medicines per encounter is 1.84 which is less than the standard value of the WHO prescribing indicator (value=2) and it indicates the prescription of drugs per person is not high (Table 2). The percentage of prescriptions with generic drug names is $67 \%$ and the drugs from the EDL is $65.8 \%$ which is less compared to WHO indicators. The percentage of prescriptions with antibiotics prescribed is $21 \%$ which is less compared to the WHO standard value.
The total number of antibiotics were 105 among 500 prescriptions (Table 3). The treatment schedule was mentioned in all the prescriptions. Among the 922 drugs $11 \%$ were antibiotics, $22.5 \%$ were antipyretics, $17 \%$ were antihistamines and the major groups of antibiotics prescribed were penicillin and cephalosporins (Figure 1).

Table 1: Socio demographic characteristics of the patient population noted from the prescriptions.

\begin{tabular}{|lll|}
\hline Variables & Range & $\begin{array}{l}\text { Number } \\
(\%)\end{array}$ \\
\hline \multirow{3}{*}{ Age (in years) } & $<5$ & 139 \\
\cline { 2 - 3 } & $5-10$ & 211 \\
\cline { 2 - 3 } \multirow{2}{*}{ Sex } & $>10$ & 150 \\
\hline
\end{tabular}

Table 2: WHO prescribing indicators.

\begin{tabular}{|lll|}
\hline $\begin{array}{l}\text { Indicators of drug } \\
\text { use }\end{array}$ & $\begin{array}{l}\text { Total drugs/ } \\
\text { encounters }\end{array}$ & $\begin{array}{l}\text { Average } \\
\text { /percent }\end{array}$ \\
\hline $\begin{array}{l}\text { Average number of } \\
\text { medicines per } \\
\text { encounter }\end{array}$ & $922 / 500$ & 1.84 \\
\hline $\begin{array}{l}\text { Percentage of } \\
\text { prescriptions with } \\
\text { generic name }\end{array}$ & 335 & 67 \\
\hline $\begin{array}{l}\text { Percentage of } \\
\text { encounters with } \\
\text { drugs prescribed } \\
\text { from essential } \\
\text { medicines list }\end{array}$ & 329 & 65.8 \\
\hline $\begin{array}{l}\text { Number of } \\
\text { encounters with an } \\
\text { injection prescribed }\end{array}$ & 0 & 0 \\
\hline $\begin{array}{l}\text { Percentage of } \\
\text { encounters with one } \\
\text { or more antibiotics }\end{array}$ & 105 & 21 \\
\hline
\end{tabular}

Table 3: characteristics of the prescription pattern of antibiotics.

\begin{tabular}{|l|l|}
\hline Indicator & $\begin{array}{l}\text { Number of } \\
\text { prescriptions }\end{array}$ \\
\hline Total number of prescriptions & 500 \\
\hline Total number of drugs prescribed & 922 \\
\hline $\begin{array}{l}\text { Number of prescriptions with } \\
\text { treatment schedule for all drugs }\end{array}$ & 500 \\
\hline $\begin{array}{l}\text { Number of prescriptions with } \\
\text { average duration of antibiotic } \\
\text { therapy }\end{array}$ & 500 \\
\hline Number of prescriptions with antibiotics \\
\hline One & 105 \\
\hline Two & 0 \\
\hline
\end{tabular}




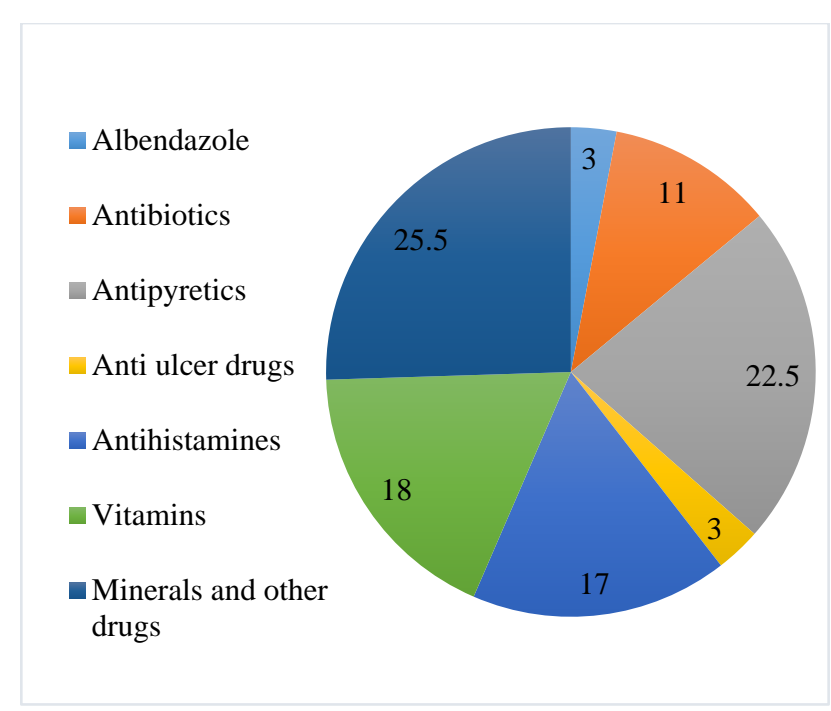

Figure 1: Frequency of distribution of various groups of drugs.

\section{DISCUSSION}

The total number of drugs used were 922 out of 500 prescriptions. The average number of drugs per prescription is a direct predictor of polypharmacy and there is no evidence of polypharmacy. ${ }^{12}$ The value from the present study is lesser than other similar studies among outpatient paediatric population reported by Kumar et al and Mishra et al. ${ }^{13,14}$

The percentage of encounters with antibiotics is around $21 \%$ which is less than the study conducted in tertiary care hospital in Northern India 79.4\% ${ }^{14}$ This result of the present study falls within the optimum range given by WHO (20.0-26.8\%) which confirms that the prescription of the antibiotics is under control. ${ }^{15}$ A total of 105 antibiotics was prescribed out of 922 drugs and since this is an outpatient study which contains the patients with mild infections the antibiotic usage is less. This may not be the same in the case of inpatient study in which all patients require antibiotics. A study reported by Kanish et al among the inpatients showed that an average of 1.9 antibiotic was prescribed per paediatric patient in a paediatric intensive care unit. ${ }^{16}$

The drugs for amoebiasis, giardiasis and other helminth infestations is not included in the antibiotics list given by WHO and therefore it is mentioned separately. ${ }^{12}$ Among the 500 children who attended the OPD around $3 \%$ were given albendazole for deworming

The percentage of the prescriptions with drugs from essential drug list is $65.8 \%$ and the value is lesser compared to WHO value. Almost $10 \%$ of the country's health care budget is spent on procuring the medicines and it is essential that the prescription of the drugs from the essential drug list also should be promoted. ${ }^{17}$
The percentage of prescriptions with drugs prescribed by generic name is $67 \%$ whereas the WHO standard value is $100 \%$. The brand names were used for the antihistamines and antibiotics. WHO and MCI encourages the physicians to write the prescriptions in the generic name, neat, legible and in capitals. ${ }^{18}$ The awareness of generic prescribing is to be promoted among the physicians can be of significant use. There were no injections among the evaluated prescriptions. The treatment schedule was mentioned in all the prescriptions.

The most commonly prescribed drugs were mainly penicillin like phenoxy methyl penicillin, amoxicillin, cloxacillin, followed by cotrimoxazole, and three prescriptions had cephalosporins. The narrow spectrum antibiotics like penicillin were majorly used and most of them are antibiotics belong to access group as per WHO AWaRe classification of antibiotics. ${ }^{19}$

\section{Limitations}

The study used just 500 prescription for analysis and the prescriptions were collected from the pharmacy rather than outpatient department. In our study we didn't analyse whether the drugs and treatment schedule in prescriptions correlate with the standard treatment guidelines. The other patient care and health facility indicators were not assessed.

\section{CONCLUSION}

The drug prescribing indicators is appropriate when compared with the WHO prescribing indicators. The antibiotic usage is around $21 \%$ which is less than the WHO optimal value. The dosage schedule was complete in almost all the prescriptions. The most commonly prescribed group of drugs are penicillin like phenoxy methyl penicillin which belong to access group of antibiotics.

Funding: No funding sources

Conflict of interest: None declared

Ethical approval: The study was approved by the Institutional Ethics Committee

\section{REFERENCES}

1. DST research study reveals usage of antibiotics highest among children. Available at http://www. pharmabiz.com/NewsDetails.aspx?aid=119706\&sid= 1. Accessed on 19 February 2020.

2. Kids up to 4 are main victims of antibiotics overprescription - The Hindu Business Line. Available at https://www.thehindubusinessline.com/news/kids-upto-4-are-main-victims-of-antibiotics-over-prescription/article30118007/ece. Accessed on 28 February 2020.

3. WHO | Use of antibiotics in children younger than two years in eight countries: a prospective cohort study. Available at: http://www.who.int/bulletin/ 
volumes/95/1/16-176123/en. Accessed on 19 February 2020.

4. Alkaff RN, Kamigaki T, Saito M, Ariyanti F, Iriani DU, Oshitani H. Use of antibiotics for common illnesses among children aged under 5 years in a rural community in Indonesia: a cross-sectional study. Trop Med Health. 2019;47(1):45.

5. Zaman SB, Hussain MA, Nye R, Mehta V, Mamun KT, Hossain N. A Review on Antibiotic Resistance: Alarm Bells are Ringing. Cureus. 2017;9(6):1403.

6. Medernach RL, Logan LK. The Growing Threat of Antibiotic Resistance in Children. Infect Dis Clin North Am. 2018;32(1):1-17.

7. Laxminarayan R, Chaudhury RR. Antibiotic Resistance in India: Drivers and Opportunities for Action. PLOS Med. 2016;13(3):1001974.

8. Ahmad A, Patel I. Schedule H1: Is it a Solution to Curve Antimicrobial Misuse in India. Ann Med Health Sci Res. 2013;3(1):55-6.

9. Hazra A. Schedule H1: Hope or hype. Indian J Pharmacol. 2014;46(4):361-2.

10. WHO. Rational use of medicines. Available at: http://www.who.int/medicines/areas/rational_use/en. Accessed on 26 August 2019.

11. Core Elements of Hospital Antibiotic Stewardship Programs | Antibiotic Use | CDC; 2020. Available at: https://www.cdc.gov/antibiotic-use/coreelements/hospital/html. Accessed on 3 March 2020.

12. How to Investigate Drug Use in Health Facilities: Selected Drug Use Indicators - EDM Research Series No. 007: Chapter 2: Core drug use indicators: Group 1: Prescribing indicators. Available at: http://apps.who.int/medicinedocs/en/d/Js2289e/3.1.ht ml. Accessed on 6 July 2019.

13. Kumar P. Assessment of antibiotic prescribing pattern in pediatric patients: A cross-sectional hospital-based survey. Available at: http://www.cjhr.org/article.asp?issn=2348-3334; year $=2017$; volume $=4 ;$ issue $=4$; spage $=235$; epage $=237$; aulast=Pradeepkumar. Accessed on 25 July 2019.

14. Mishra H, Mishra R, Mondal A. Prescription pattern of antimicrobial drugs in pediatrics outpatient department of a tertiary care teaching hospital of North India. Int $\mathbf{J}$ Basic Clin Pharmacol. 2017;3(2):385-8.

15. Asenso OR. A closer look at the World Health Organization's prescribing indicators. J Pharmacol Pharmacother. 2016;7(1):51-4.

16. Kanish R, Gupta K, Juneja S, Bains HS, Kaushal S. Prescribing pattern and pharmaco-economics of antibiotic use in the department of pediatrics of a tertiary care medical college hospital in northern India. Ann Trop Med Public Health. 2015;8(4):101.

17. Concept of Essential Medicines and Rational Use in Public Health. Available at: https://www.ncbi.nlm. nih.gov/pmc/articles/PMC2888334. Accessed on 5 March 2020.

18. Prescription writing: Generic or brand. Available at https://www.ncbi.nlm.nih.gov/pmc/articles/PMC5547 850. Accessed on 5 March 2020.

19. WHO releases the 2019 aware classification antibiotics. Available at: http://www.who.int/ medicines/news/2019/WHO_releases2019AWaRe_cl assification_antibiotics/en. Accessed on 4 March 2020.

Cite this article as: Priyadharsini RP, Kesavan R. Antibiotic prescribing pattern among paediatric patients attending tertiary care hospital in South India. Int J Basic Clin Pharmacol 2020;9:1028-31. 